\title{
Intellectual Property, Health, Regionalism and Development: A Third World's Perspective
}

\author{
Olasupo Owoeye ${ }^{1}$
}

\begin{abstract}
The United Nations Sustainable Development Goals were adopted in September 2015 as a post 2015 development agenda. Goal 9 of the SDGs is to 'build resilient infrastructure, promote inclusive and sustainable industrialization and foster innovation'. Much has been written on the connection between intellectual property and development. With respect to developing countries, arguments have been canvassed both for and against intellectual property in the pursuit of their development goals. The adoption of the TRIPS Agreement in 1994 heralded a new era of global intellectual property governance aimed at a substantial harmonisation of intellectual property protection standards across the globe. This continues to raise continuing concerns in relation to the extent to which IP could foster development and industrialisation in developing countries and whether the global IP regime is designed in a way that sufficiently protects the interest of the developing and least developed nations. The development rhetoric is assuming an increasing significance in Africa given the continent's varying development challenges. This calls for some reflection on the interface between IP protection and the pursuit of sustainable human and economic development. The paper examines the link between intellectual property and health and how it relates to sustainable development in the African context.
\end{abstract}

\section{Introduction}

The United Nations Sustainable Development Goals were adopted in September 2015 as a post 2015 development agenda. ${ }^{1}$ Goal 9 of the SDGs is to build resilient infrastructure, promote inclusive and sustainable industrialization and foster innovation'. ${ }^{2}$ Intellectual property is very important to the development of infrastructure, sustainable industrialisation and the promotion of innovation. Much has been written on the connection between intellectual property and development. With respect to developing countries, arguments have been canvassed both for and against intellectual property (IP) in the pursuit of their development goals. The adoption of the Agreement on Trade Related Aspects of Intellectual Property Rights (TRIPS Agreement) ${ }^{3}$ in 1994 heralded a new era of global intellectual property governance aimed at a substantial harmonisation of intellectual property protection standards across the globe. This continues to raise

${ }^{1}$ UN General Assembly, Transforming our World: The 2030 Agenda for Sustainable Development, UN Resolution No.A/RES/70/1.

2 Ibid

3 Marrakesh Agreement Establishing the World Trade Organisation, opened for signature April 15, 1994;

1867 U.N.T.S. 3 (entered into force January 1, 1995), Annex 1C, Agreement on Trade Related Aspects of Intellectual Property Rights. 
continuing concerns in relation to the extent to which IP could foster development and industrialisation in developing countries and whether the global IP regime is designed in a way that sufficiently protects the interest of the developing and least developed nations. The development rhetoric is assuming an increasing significance in Africa given the continent's varying development challenges.

In November 2015, the text of the Trans Pacific Partnership Agreement was made publicly available. The TPP contains a number of provisions requiring a stronger protection for intellectual property than the level envisaged by the TRIPS Agreement. ${ }^{4} \mathrm{~A}$ day after the release of the official text of the TPP, the World Trade Organization extended the exemption granted to Least Developed Countries to delay the implementation of IP standards under the TRIPS Agreement to 2033 in recognition of their development challenges. ${ }^{5}$ The year 2016 marks the 30th anniversary of the adoption of the United Nation Declaration on the Right to Development. It is therefore an opportune time to reflect on the interface between IP protection and the pursuit of sustainable human and economic development. The paper seeks to examine the link between IP and health and how it relates to sustainable development in the African context. The paper will consider options that African nations may consider in the implementation of IP laws that are development oriented.

Sustainable development has been defined as "development that meets the needs of the present without compromising the ability of the future generations to meet their own needs." There has been a proliferation of regional trade agreements (RTAs) in recent years. While RTAs are seen as regional blocs that seek to facilitate the realisation of a truly multilateral system, building RTAs with sustainable development strategies remain a significant challenge. ${ }^{7}$ Sustainable development is one of the cardinal objectives of the EU as enunciated in the Treaty of Lisbon. The EU has developed a Sustainable Development Strategy to facilitate its attainment of sustainable development through the efficient use of resources, ecological innovation and the protection of the environment. ${ }^{8}$ The EU has also adopted the practice of including a "Trade and Sustainable Development' chapter in the RTAs it negotiates. ${ }^{9}$ The EU is presently negotiating a trade and investment agreement with the US. The Transatlantic Trade and Investment Partnership (TTIP) is a bilateral agreement being negotiated between the US and Europe and its main objective, according to the European Commission, is to enable European

${ }^{4}$ See Pete Dolack, The TPP - blueprint for the 1000-year Reich of global capital, 16 November 2015, Ecologist, available at http://www.theecologist.org/News/news analysis/2986290/the tpp blueprint for the 1000year reich of global capital.html (accessed 16/02/16).

${ }^{5}$ See WTO, 2015 New Items: WTO members agree to extend drug patent exemption for poorest members available at https://www.wto.org/english/news_e/news15_e/trip_06nov15_e.htm (accessed 16/02/2016)

6 The World Commission on Environment and Development's report, Our Common Future, Oxford: Oxford University Press, 1987

7 Rafael Leal-Arcas, Mega-Regionals and Sustainable Development: The Transatlantic Trade and Investment Partnership and the Trans-Pacific Partnership (2015) 6 Renewable Energy Law and Policy Review 248

8 'Renewed Sustainable Development Strategy' (European Commission, 15/16 June 2006)

9 'EU - US Transatlantic Trade and Investment Partnership: Trade and Sustainable Development: Initial EU Position Paper' (European Commission) 2 
firms, however small or large and irrespective of the nature of their business, to get easier access to the foreign markets outside Europe. ${ }^{10}$ The EU, in its Initial Position Paper on trade and sustainable development in the TTIP, observes that sustainable development is an overarching policy goal of the global community and social advancement, economic development and environmental protection are all 'mutually reinforcing components of sustainable development'. ${ }^{11}$ The EU notes that the Trade and Sustainable Development chapter of the TTIP should contain, in particular, provisions that promote, trade and investment in climate friendly goods and technologies, ethical and fair trade initiatives, and corporate social responsibily obligations. ${ }^{12}$

While developing and least developed countries clearly constitute the majority with respect to W'TO membership, their bargaining power against developed nations is very weak and almost ineffective. ${ }^{13}$ The inability of the WTO to conclude the Doha Development round which started as far back as 2001 has been identified as a classic illustration of the considerable divide between developed and developing countries in the WTO. ${ }^{14}$ The implication of TRIPS for technology transfer is also an issue that can have significant effect on economic growth. ${ }^{15} \mathrm{~A}$ classic argument for the recognition and enforcement of intellectual property law is that IP protection enables innovators and creators of novel product to recoup the cost of their investment in developing the innovative product or creative work and IP is thus essential to scientific progress and innovation. ${ }^{16}$ Foreign investors whose IP rights are violated by individuals in a different country may have no recourse except the violation can be attributed to the activities of the host country. ${ }^{17}$ IP protection, especially in relation to pharmaceutical patents, may however pose a significant access to medicines challenge and further aggravate the public health problem in developing countries. The protection of IP therefore requires a fair balance between the rights of the IP holders and the public interest in having reasonable access to IP protected goods and enjoying the benefits of scientific progress.

${ }^{10}$ European Commission, How TTIP would work, http://ec.europa.eu/trade/policy/in-focus/ttip/aboutttip/contents/ (accessed 24/04/16).

${ }^{11}$ EU - US Transatlantic Trade and Investment Partnership: Trade and Sustainable Development: Initial $\begin{array}{lllll}\text { EU Position } & \text { Paper' } & \text { (European } & \text { Commission) } & 1\end{array}$ http://trade.ec.europa.eu/doclib/docs/2013/july/tradoc_151626.pdf

12 Ibid 3

13 Cecily Anne O'Regan \& Patrick T. O'Regan Jr., USING GATT-TRIPS TO IMPROVE DEVELOPMENT

OPPORTUNITIES: A PROPOSAL FOR CENTRAL AMERICA (2015) 7 Hastings Science \& Technology Law Journal 1, 4

14 Ibid

15 Julien Chaisse \& Puneeth Nagaraj, CHANGING LANES: INTELLECTUAL PROPERTY RIGHTS, TRADE AND INVESTMENT (2014) 37 Hastings International and Comparative Law Review 223, 226

16 See Ho, "Patent Breaking or Balancing?"(2009) 34 North Carolina Journal of International Law \& Commercial

Regulation, 371, 463-464.

17 Julien Chaisse \& Puneeth Nagaraj, CHANGING LANES: INTELLECTUAL PROPERTY RIGHTS, TRADE AND INVESTMENT (2014) 37 Hastings International and Comparative Law Review 223, 226 


\section{Health, Development and WTO Law}

In the area of public health, HIV and AIDS continue to wreak havoc in the world's poorest regions especially in Africa with the highest global disease burden and the highest rate of HIV infection in the world. ${ }^{18}$ Sub-Sahara Africa currently accounts for about $70 \%$ of new HIV infections worldwide. ${ }^{19}$ The HIV scourge is undoubtedly a major threat to social economic development in Africa. As clearly elucidated by Rudolf V Puymbroeck,

While HIV strikes both rich and poor, the poor suffer the greatest impact. Conversely, poverty is itself a driver of HIV and AIDS: under-nutrition, unsanitary conditions, parasite infections, inadequate primary health care, illiteracy, economic insecurity and a precarious ability to cope with the financial repercussions of illness and death all increase poor people's susceptibility to HIV and AIDS.'20

HIV infection results in higher mortality in poorer regions where access to basic health care facilities is largely lacking. There is in fact a causal connection between HIV and poverty as poverty is intricately linked with under-nutrition which in turn increases susceptibility to infections and diseases including HIV and AIDS. ${ }^{21}$ Harsh social economic conditions may also affect people's desire to maintain good health standard and this may make those frustrated with their social economic circumstances to embrace reckless lifestyles including risky sexual behaviours. ${ }^{22}$

WTO Law is very relevant to public health and human development in third world countries especially in Africa in two significant ways. First, if trade rules are designed in a way that makes the pursuit of development unnecessarily cumbersome for developing countries, there will be less favourable social economic conditions in such countries. Trade rules that reflect the principles embodied in the right to development will ultimately result in lower incidences of malnutrition and a higher spate of infrastructural development which will make life more meaningful to populations in developing countries. Second, the WTO intellectual property regime, especially in the field of patents, must be construed in a way that allows for the legitimate use of the flexibilities under the WTO Agreement on Trade Related Aspects of Intellectual Property Rights in a manner reflective of the social economic circumstances of member states. ${ }^{23} \mathrm{~A}$ strict interpretation of the WTO TRIPS Agreement will make access to new medicines in poorer countries more of an impossible aspiration than a realistic goal. The existing flexibilities in WTO Law must therefore be allowed to have more legal force in their real application as against their hitherto largely rhetorical theoretical underpinnings.

It has been argued, for instance, that the distribution of benefits arising from

18See WHO, Global Update on the Health Sector Response to HIV 2014 (WHO 2014) 3

19WHO, HIV/AIDS Factsheet, July 2015 available at http://www.who.int/mediacentre/factsheets/fs360/en/.

20Rudolf V Puymbroeck, 'Beyond Sex: Legal Reform for HIV/AIDS and Poverty Reduction', (2008)

Georgetown Journal on Poverty Law \& Policy 781 (2008), at 782

${ }^{21}$ Ibid at 783

22Ibid at 788

${ }^{23}$ See generally Dianne Nicol and Olasupo Owoeye, 'Using TRIPS Flexibilities to Facilitate Access to Medicines', 91(7) Bulletin of the World Health Organization 533 (2013). 
international trade has not really taken Africa's peculiar position into account thereby resulting in a continual fall in the continent's share in international trade. ${ }^{24}$ Whilst developing countries have succumbed to the pressure to liberalise trade and keep their markets open, the most powerful developed countries have not been very willing to grant the reciprocal concessions desired by developing economies. ${ }^{25}$

International developments and concerns over the connection between health and international trade have made the health implication of trade liberalisation an issue of relevance to the regional integration debate. ${ }^{26}$ There have been significant concerns over the impact of international trade regimes on public health. ${ }^{27}$ The WTO Doha Declaration on the TRIPS Agreement and Public Health expressly recognises the fact that trade in pharmaceutical products protected by intellectual property may result in a public health conundrum and WTO member states are enjoined not to pursue their rights and obligations under the TRIPS Agreement in a way that may impede access to medicines for all. ${ }^{28}$

People in the developing world continue to contend with heightened vulnerability due to public health disasters caused by increased migration, injurious environmental factors and technological change. ${ }^{29}$ The recent resurgence of the Ebola virus in West Africa with its incursion into the United States and Europe within weeks of the outbreak in the region clearly shows that diseases are not easily constrained by border restrictions. ${ }^{30}$ Addressing the public health conundrum in Africa and other parts of the world facing a serious diseases burden would require concerted efforts which may require pooling resources together internationally and regionally to spur national actions to control the spread of communicable diseases. ${ }^{31}$

It has been argued that globalisation has contributed to the public health crisis in the developing world as transnational trade has contributed to the international transfer of disease pathogens and harmful products. ${ }^{32}$ Poverty and poor health are very intertwined and social theories of public health and infections show that socio-economic status and the standard of living of the general population influence health. ${ }^{33}$ People with the adequate access to important resources are better equipped to avoid the risk of diseases

${ }^{24}$ Nsongurua J Udombana, 'A Question of Justice: The WTO, Africa and Countermeasures for Breaches of International Trade Obligations (2005) 38 The John Marshall Law Review 1153, 1155.

${ }^{25}$ Ibid

${ }^{26}$ William Onzivu, Globalism, Regionalism, or Both: Health Policy and Regional Economic Integration in Developing Countries, an Evolution of a Legal Regime? 15 Minnesota Journal of International Law 111 (2006), 112.

27Ibid 113 .

28 Doha Ministerial Declaration on the TRIPS Agreement and Public Health, WT/MIN(01)/Dec/2 (November 20, 2001) (Adopted November 14, 2001) para.4 (Doha Declaration).

${ }^{29}$ Tony McMichael \& Robert Beaglehole, The Global Context for Public Health, in Robert Beaglehole and Ruth Bonita (eds.) Global Public Health: A New Era (Oxford, Oxford University Press, 2009) 1-22 at 11.

30See BBC News: Ebola: Mapping the outbreak (19 June 2015) available at http://www.bbc.com/news/world-africa-28755033.

${ }^{31}$ William Onzivu, above n26, at 116.

32Derek Yach \& Douglas Bettcher, The Globalization of Public Health: Threats and Opportunities, 88 Am. J. Pub. Health 735, (1998) 735.

33WHO, The World Health Report 2003: Shaping the Future, 5-22 (Oct. 2003) (prepared by

Robert Beaglehole) 
and to mitigate the consequences in the event of its occurrence. ${ }^{34}$ Many studies have already demonstrated the link between health and economic development. ${ }^{35}$ Indeed, many of the public health threats in developing nations are not only health threats but also threats to the economic development of those countries. ${ }^{36}$ Health can be viewed as a public good as the prevention of a communicable disease in one person produces a positive consequential outcome by reducing the risk of infecting others. ${ }^{37}$ Health as a public good should therefore be promoted through international and regional efforts and it should be adequately protected by international economic law. ${ }^{38}$

There is a growing body of international health law made up of several multilateral treaties and regulations that are geared towards the enhancement of public health. ${ }^{39}$ The invocation of international law is therefore becoming a major strategy for the promotion of global health. ${ }^{40}$ International health law covers issues such as human reproduction, diseases, drugs, food safety and other ancillary matters. ${ }^{41}$ Various international organisations, including the WTO, World Health Organisation (WHO) and the United Nations (UN) have continued to promote public health in developing nations through policy, law and practice. ${ }^{42}$

The WTO legal regime can be an effective tool of public health protection in developing nations. ${ }^{43}$ Under WTO law, protection of life or public health can be a valid ground for derogating from certain WTO obligations. ${ }^{44}$ International trade may sometimes involve trade in goods that are harmful to public health. For instance, regional trade agreements sometimes involve the liberalisation of trade in tobacco products resulting in the influx of cheap tobacco products which may be harmful to public health in such countries ${ }^{45}$

The WTO Appellate Body has held that countries are at large to adopt measures necessary to protect health. The WTO Dispute Settlement Panel, in a decision that was later affirmed by the Appellate Body held thus:

... the EC has made a prima facie case for the existence of a health risk in connection with the use of chrysotile, in particular as regards lung cancer and mesothelioma in the occupational sectors downstream of production and processing and for the public in general in relation to chrysotile-cement products. This prima facie case has not been rebutted by Canada. Moreover, the Panel considers that the comments by the experts confirm the health risk associated with exposure to chrysotile in its various uses. The

\footnotetext{
${ }^{34}$ William Onzivu, above $\mathrm{n} 26$ at 117.

${ }^{35}$ See WHO, Commission on Macroeconomics \& Health [CMH], Macroeconomics and Health: Investing in Health for Economic Development, 57-59 (Dec. 20, 2001) (presented by Jeffrey D. Sachs);

${ }^{36}$ Ibid 53

${ }^{37}$ William Onzivu, above n 26, at 118

38 Ibid

${ }^{39}$ See David Fidler, A Globalized Theory of Public Health Law, 30 J.L. Med. \& Ethics 150 (2002).

${ }^{40}$ William Onzivu, above n 26, at 125.

${ }^{41} \mathrm{Ibid}$

42Ibid at 126 .

${ }^{43}$ M. Gregg Bloche \& Elizabeth R. Jungman, Health Policy and the WTO, 31 J.L. Med. \& Ethics 529, 530$31(2003)$

${ }^{44}$ See GATT Article XX(b)

${ }^{45}$ Douglas Bettcher et al., Confronting the Tobacco Epidemic in an Era of Trade Liberalization (WHO, 2001)

$49-50$
} 
Panel therefore considers that the EC have shown that the policy of prohibiting chrysotile asbestos implemented by the Decree falls within the range of policies designed to protect human life or health. ${ }^{46}$

Developing nations therefore have the power under WTO law to adopt measures aimed at safeguarding the health of their populations. Such measures may include the adoption of a liberal interpretation of the flexibilities available under the TRIPS Agreement. This position clearly finds support in the Doha Declaration on TRIPS and Public Health where the WTO Ministers declare that the TRIPS Agreement 'should be interpreted and implemented in a manner supportive of WTO members' right to protect public health and, in particular, to promote access to medicines for all'. ${ }^{47}$

Regionalism in Europe has shown that regional trade arrangements can incorporate policies that serve public health goals. ${ }^{48}$ The EU Health Law framework is embodied in a number of public health directives. ${ }^{49}$ Under the Treaty Establishing the European Community, the European Community has an obligation to ensure a high level of human health protection in the implementation of its policies. ${ }^{50}$ The EU has played a crucial role in the harmonisation of public health norms in areas relating to tobacco control and occupational health. ${ }^{51}$ The EU is also committed to the provision of financial and technical support for the enhancement of public health in developing countries. ${ }^{52}$ Article 73 of the Treaty Establishing the African Economic Community (otherwise known as the Abuja Treaty) enjoins African countries to promote cooperation with respect to health care delivery and to adopt collaborative measures in developing primary health care and fostering medical research. ${ }^{53}$ The Treaty Establishing the Common Market for Eastern and Southern Africa contains provisions on the promotion of public health. ${ }^{54}$ In a similar vein, the East African Community Treaty also has provisions on the protection and promotion of health. ${ }^{55}$ It is very important for developing countries to prioritise public health issues and be fully involved in the development of public health policy making at international and regional levels. ${ }^{56}$

${ }^{46}$ European Communities - Measures Affecting Asbestos and Asbestos-Containing Products WT/DS135/R, 18 September 2000 para. 8.194.; European Communities - Measures Affecting Asbestos and Asbestos-Containing Products WT/DS135/AB/R 12 March 2001 para 157

${ }^{47}$ Doha Declaration n 28 above, para 4.

${ }^{48}$ Treaty Establishing the European Community art. 100, Nov. 10, 1997, 1997 O.J. (C 340) 3

${ }^{49}$ See, e.g., See Communication on the Framework for Action in the Field of Public Health, COM (93) 559

(November 24, 1993). Council Directive 2003/33/EC, 2003 O.J. (L 152) 16; Council Directive 2004/33/EC, 2004 O.J. (L 102) 48; Council Directive 2002/98/EC, 2002 O.J. (L 33$) 30$.

${ }^{50} \mathrm{EC}$ Treaty art 129

${ }^{51}$ See, e.g., Council Directive 92/29 1992 OJ(L 113) 19 (EC) ( standards for medical treatment on ships); Council Directive 80/1107, 1980 OJ(L327) 8 (EC) (protecting occupational health); European Union, Manufacture, Sale, and Presentation of Tobacco Products (2003).

52Partnership Agreement Between the Members of the African, Caribbean and Pacific Group of States of the

One Part, and the European Community and its Member States, of the Other Part, June 23, 2000 (hereinafter called Cotonou Agreement) art. 25

${ }^{53}$ Treaty Establishing the African Economic Community Article 73

${ }^{54}$ Treaty Establishing the Common Market for Eastern and Southern Africa, art. 50(c), 110, Nov. 5, 1993,

33 I.L.M. 1067

55East African Community Treaty, Kenya-Uganda-Tanz., Nov. 30, 1999

56William Onzivu above n26, at 186. 
Developing countries may therefore use the machinery of RTAs to not only liberalise trade but to also address issues such as protection of public health, labour and the environment.

Regionalism can thus be used to promote public health especially in Africa. Boosting intra African trade through the creation of a continent wide regional trade agreement can be a way of addressing a number of salient socio economic issues through the paradigm of trade cooperation. It can lead to the facilitation of medical research, pharmaceutical innovation, stronger use of compulsory licensing for public health purposes in Africa and a bigger and more affordable market for medical products.

\section{Conclusion}

The extent to which IP affects access to medicines and public health in developing countries is an issue that continues to attract a wide range of commentaries. New regional agreements are constantly being negotiated by advanced economies to strengthen IP rights sometimes beyond the standard negotiated under the TRIPS Agreement. The proliferation of free trade agreements across the globe and the increasing emphasis on IP in many trade agreements may have effects on public health and human development in many third world countries. In the African context, there is a growing need for a regional approach to the access to medicines conundrum and the human development challenge. The continent can adopt a development oriented IP policy that will ensure IP laws are implemented in a way that enhances local pharmaceutical innovation, easier access to essential drugs and human development. The various regional economic communities in the continent are strategically positioned to begin the process of harmonising the existing frameworks for IP protection in the continent and may do this in a way that sufficiently takes into cognisance the development needs of their populations. 